\title{
Health and human rights: a statistical measurement framework using household survey data in Uganda
}

\author{
Ronald Wesonga*, Abraham Owino ${ }^{\dagger}$, Agnes Ssekiboobo $^{\dagger}$, Leonard Atuhaire ${ }^{\dagger}$ and Peter Jehopio ${ }^{\dagger}$
}

\begin{abstract}
Background: Health is intertwined with human rights as is clearly reflected in the right to life. Promotion of health practices in the context of human rights can be accomplished if there is a better understanding of the level of human rights observance. In this paper, we evaluate and present an appraisal for a possibility of applying household survey to study the determinants of health and human rights and also derive the probability that human rights are observed; an important ingredient into the national planning framework.

Methods: Data from the Uganda National Governance Baseline Survey were used. A conceptual framework for predictors of a hybrid dependent variable was developed and both bivariate and multivariate statistical techniques employed. Multivariate post estimation computations were derived after evaluations of the significance of coefficients of health and human rights predictors.

Results: Findings, show that household characteristics of respondents considered in this study were statistically significant $(p<0.05)$ to provide a reliable assessment of human rights observance. For example, a unit increase of respondents' schooling levels results in an increase of about 34\% level of positively assessing human rights observance. Additionally, the study establishes, through the three models presented, that household assessment of health and human rights observance was $20 \%$ which also represents how much of the entire continuum of human rights is demanded.

Conclusion: Findings propose important evidence for monitoring and evaluation of health in the context human rights using household survey data. They provide a benchmark for health and human rights assessments with a focus on international and national development plans to achieve socio-economic transformation and health in society.
\end{abstract}

Keywords: Human rights, Health indicators, Statistical models, Household survey

\section{Background}

Health is intertwined with human rights as is clearly reflected in the right to life which is a basis for enjoyment of all other human rights. Promotion of health practices in the context of human rights can be accomplished if there is a better understanding of the level of human rights observance. Human rights indicators are therefore critical to the health of society and the national development agenda and can be classified into three categories namely; i) structural indicators that reflect the

\footnotetext{
*Correspondence: wesonga@wesonga.com

tEqual contributors

School of Statistics and Planning, Makerere University, Kampala, Uganda
}

ratification or adoption of legal instruments and existence of basic institutional mechanisms deemed necessary for facilitating realisation of the concerned human right; ii) process indicators that relate the state policy instruments with milestones which accumulate into outcomes that can be more directly related to realisation of a right, hence capture accountability as well as the notion of progressive realisation; and iii) outcome indicators that capture attainments, individual and collective, and reflect the status of realisation of the human rights in a given context [1-4]. Statistics on the other hand renders a scientific approach to the development, assessment and monitoring of human rights indicators 
$[5,6]$. Hitherto, accuracy in developing statistically reliable human rights indicators has not been given the attention it deserves, probably not because of the process complexity, but maybe because of the fact that it is an assumed psychometric area of statistical application.

However, initiatives have been undertaken to scientifically conceptualise human rights so as to develop statistically reliable human rights indicators. For instance, there are four main categories and three dimensions of human rights. The four categories are; economic, political, social and cultural (EPSC) rights while the three dimensions are; respect, protect and fulfil $[1,7,8]$. These categorisations form the fulcrum of statistical measurement of human rights [7,9-11]. Furthermore, the initiatives so far taken towards development of human rights indicators could be categorised as; event-based data on human rights violations, socio-economic and administrative statistics, household perceptions and opinion surveys, and expert judgements $[4,12]$. In response to these requirements, Uganda conducted the first ever governance baseline survey that among other themes collected data on human rights to inform the national development agenda [13-15]. In this paper, we assess the determinants of human rights and develop models for measuring human rights observance at the national-level that would be a source for monitoring health and socioeconomic development goals. Subsequently, the following propping questions might be answered: What are the key determinants of human rights? Are there variations in the parameters that explain human rights? How much of the human rights continuum do the identified parameters explain? Are there variations in the different models that explain human rights observance?

Three core aspects namely; definition, measurement and prediction have greatly affected appreciation and localisation of human rights in the political, cultural, economic and social spheres of humanity [16,17]. The complexity to human rights stems from the level of difficulty to define human rights whereas the failure to make reliable prediction could be due to unavailability of a reliable approach to measure and monitor the human rights [18,19]. A number of scholars [20,4,21] have attempted to provide some definitions, but to-date there is no single definition of human rights that is acceptable as a standard by all those fighting for human rights. Surprisingly, in this modern era, there are still some sections of humanity and other cultures that do not believe, for example that women are human beings and as such should not prescribe to human rights $[22,8,23]$. In his book, [24] contends that although a human right is a strong idea, it is often used loosely and can have different meanings in different contexts and those who use the idea so readily seldom stop to ponder its various meanings and contradictions. Nonetheless, human rights are described as universal legal guarantees that protect the fundamental freedoms and human dignity of every individual [16,10,2,21]. They affirm that every human being is entitled to equal treatment and opportunities regardless of belonging to any section of society.

It is often said that to manage, you must be able to measure, conversely, what you cannot measure, you cannot manage. For human rights to be understood, defended, localised in promotion of health outcomes for the deprived societies, measurable indicators must be developed to reflect the local context of a region or country [11]. It is imperative that such indicators be developed to cover the five categories of human rights; civil, economic, political, social and cultural rights against the three dimension of respect, protect and fulfil.

Theoretically, a household is at the core of health and human rights assessments because it is within a household that humans live. Therefore, to understand health and human rights and be able to assess and predict them, the theoretical and conceptual designs have to focus at a household as a data source [25]. In this context, a national governance baseline survey carried out with household as the unit of analysis, yielded the desired data for assessing human rights. The Uganda National Governance Baseline Survey was carried out with a focus on five key themes of governance, among which was the theme on human rights, details on this will be presented in the section on data sources and description and more details can be found in the report [26]. Theoretically, it is well conceptualised that the status of health and well-being of a person is premised on the degree to which he enjoys the human rights $[13,27,28]$. The more the human rights are denied or the tendency therein, the less likely that such a person is happy and healthy. In this regard, a dependent variable that aggregates the three dimensions of respect, protect and fulfil, was thus, developed to take cognizance of the three dimensions of human rights. The composite indicator variable is adequately described in the preceding sections. To assess levels of human rights adequately at household level depends on the level of awareness about the economic, political, social, cultural and civil human rights. Therefore, one can at statistical confidence level tell whether, human rights are respected or not. However, there are variations in degrees of awareness and even respect for human rights by respondent's demographic, educational, employment and disability characteristics which are also moderated by location and availability of services in their localities as shown in Figure 1.

Violation of one's right to housing leads to violation of various other rights because these rights are inter-related [29-31]. According to UNHCHR [31], "Inadequate housing can have repercussions on the right to health; for instance, if houses and settlements have limited or no safe 


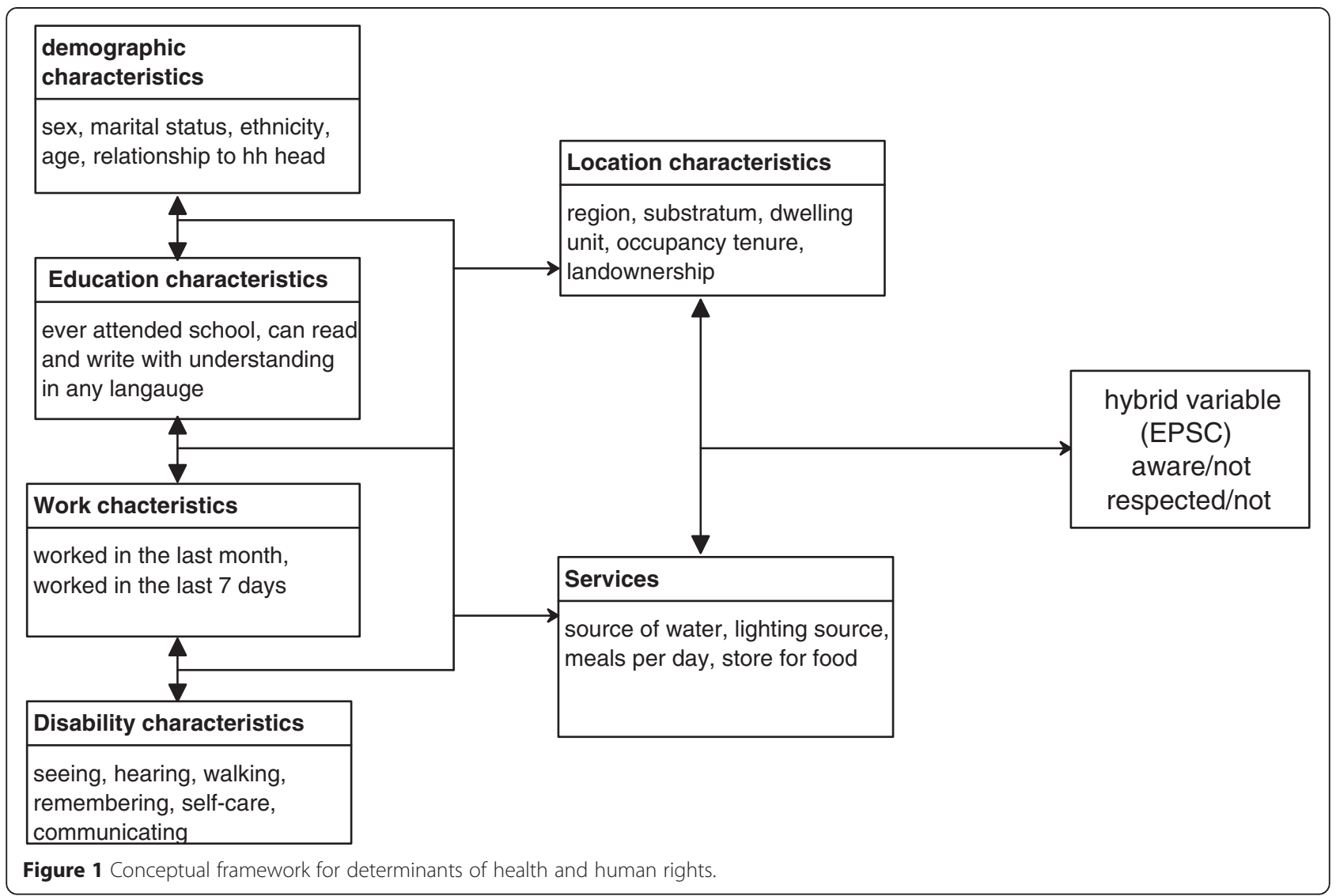

drinking water and sanitation, their residents may fall seriously ill." Inadequate housing may also imply lack of or poor food storage facilities thus affecting food availability, food access and food quality [32]. UNHCHR [31] also notes that the right to adequate housing can be affected by the extent to which other human rights are guaranteed, for instance, access to housing is most at risk for those denied the right to education, work or social security. Employment status, education and dwelling decency are among the variables considered in this study. Quality of housing is strongly associated with wellbeing as shown by the fact that inadequate housing increases the risk of severe ill health and disability and even poor mental health. It is also associated with lower educational attainment, unemployment and poverty [33,34]. The UN Committee [35] stated that housing must provide adequate shelter, which means adequate privacy, space, security, lighting and ventilation, basic infrastructure and location with regard to work and basic facilities, all at a reasonable cost. The variables that focus on the right to housing (housing condition, status and location) in this study include rural/urban and regional locations, decency of the dwelling unit, ownership status for both house and land and source of lighting. The Convention on the Rights of the Child [36] also stipulates that everyone should have a right to sustainable access to natural and common resources, safe drinking water, energy for cooking, heating and lighting, sanitation and washing facilities, means of food storage, refuse disposal, site drainage and emergency services. In this study the variables considered from this list were source of water, meals per day and granary status for food storage.

\section{Methods}

Data sources and description

The data used in this paper were derived from the Uganda National Governance Baseline Survey (UNGBS) conducted by the Uganda Bureau of Statistics in collaboration with Makerere University, School of Statistics and Planning, with support from the United Nations Development Programme. A national sample of 4776 households was scientifically drawn and data collected on various themes of governance among which was the theme on human rights. Table 1 shows eighteen variables that were carefully chosen for this study, whereof the last variable, human rights respect, $h r_{-}$hybrid is the dependent variable of the models developed. This variable was developed to capture both aspects of knowledge of a human right and being able to assess the observance of human rights [37]. In most developing countries and largely so, many citizens may not be aware of some of their rights! Therefore, a condition was 
Table 1 Description of variables for the framework

\begin{tabular}{ll}
\hline Variable & Variable description \\
\hline Urbanrural & urban or rural residence \\
Region & Region \\
Age & age of respondent \\
Hhhead & head of household \\
Mstatus & marital status \\
Readwrite & can read and write \\
Attendschool & ever attended school \\
Employstatus & employment status \\
Dwelling & dwelling unit decency status \\
Ownhouse & house ownership status \\
Watersource & source of water \\
Lighting & source of lighting \\
Ownland & land ownership status \\
Granary & granary presence \\
Sex & sex of respondent \\
Disability & disability status \\
Meals & meals per day \\
hr_hybrid & Human rights respect \\
\hline
\end{tabular}

developed to the effect that if one is not knowledgeable enough about some right, then that person does not have a sufficient ground to assess the level of observance of such a right. Thus, the development of a hybrid dependent variable that reliably measures both knowledge and assessment of human rights [38].

\section{Framework for health and human rights level of observance}

A conceptual framework was developed to show the relationship that exists between the independent variables and the hybrid dependent variable for the study as shown in Figure 1. The hybrid dependent variable was derived such that it covered knowledge and assessment aspects of economic, political, social and cultural human rights with health treated as a crosscutting indicator. For example, knowledge on the right to seek for justice under the law, the right of victims, suspects, accused persons, prisoners, and the right to vote, access information, among others were considered. The independent variables used in the modelling process are primarily for the typical citizens' characteristics, intervened by location and services' characteristics $[39,27,5,40]$. Table 1 shows a description of variables used to assess health and human rights at household level. Specific independent variables were categorised under demographic, educational, work and disability characteristics. The other categories, location and availability of services were used as intervening variables. The purpose was to explore the effect of belonging to a certain category on assessment of the level of health and human rights observance.

The fact that the stochastic structure of the data are expressed in terms of Bernoulli and Binomial distributions; whereby the hybrid dependent variable ( $h r$ _hybrid) bore two categories (aware/respected vis-a-vis not aware/respected), implied the application of binary logistic regression modelling approach [41,42]. Accordingly, the conceptual framework implied development and comparison of three logit models. In the logistic regression model, the random variable $Y_{i}$ is assumed to have a binomial distribution;

$$
Y_{i} \sim \operatorname{Binomial}\left(n_{i}, \pi_{i}\right)
$$

which then defines the stochastic structure of the model with a binomial denominator $n_{i}$ and probability $\pi_{i}$ We suppose that the logit of the underlying probability $\pi_{i}$ is a linear function of the predictors for human rights as shown in Figure 1, then;

$$
\operatorname{logit}\left(\pi_{i}\right)=X_{i}^{\prime} \beta
$$

Where $X_{i}$ a vector of covariates for human rights and $\beta$ is a vector of regression coefficients for the covariates. Thus, Equations (1) and (2) define generalised linear models for determinants of human rights with binomial response and logit link $[43,44]$. The findings presented in Table 2 for the three models are each derivatives of the logit model described as in Equation 2.

\section{Ethical consideration}

This study used secondary data collected by the Uganda Bureau of Statistics, which is entitled by Ugandan law to collect and disseminate official statistics. The data were anonymised so as to conceal the identity of the household respondents, as is the required.

\section{Results}

\section{Relationship between health and human rights} observance and its covariates

Table 2 presents the bivariate analysis to establish the relationships between human rights observance and its explanatory variables. Using the chi-squared and the design-based F-tests, the relationship between eight of the seventeen candidate variables and human rights observance were statistically significant $(p<0.05)$, four variables were marginally statistically significant $(p \approx 0.05)$ while five variables were statistically not significant $(p>0.05)$.

\section{Models for determinants of health and human rights observance}

Table 3 presents three multivariate statistical models that explain human rights observance at the national level. The difference between the three models is the 
Table 2 Factors associated with health and human rights (knowledge and assessment) Health and human rights observance (knowledge and assessment)

\begin{tabular}{|c|c|c|c|c|c|}
\hline & \multicolumn{2}{|c|}{ HR not respect } & \multicolumn{2}{|c|}{ HR respected } & \multirow{2}{*}{$\begin{array}{l}\text { Test statistic } \\
\mathrm{x}^{2} / \mathrm{F} / \mathrm{p} \text {-value }\end{array}$} \\
\hline & Percent & 95 Percent $\mathrm{Cl}$ & Percent & 95 Percent $\mathrm{Cl}$ & \\
\hline \multicolumn{6}{|l|}{ Region } \\
\hline Kampala & 74.8 & {$[70.9-78.3]$} & 25.2 & {$[21.7-29.1]$} & \multirow{6}{*}{$\begin{array}{l}X^{2}(4)=40.7943 ; \text { Design-based } F(3.48 \\
16594.36)=7.6073 \mathbf{P}=\mathbf{0 . 0 0 0}\end{array}$} \\
\hline Central & 87.6 & {$[85.1-89.7]$} & 12.4 & [10.3-14.9] & \\
\hline Eastern & 80.8 & {$[77.5-83.7]$} & 19.2 & {$[16.3-22.5]$} & \\
\hline Northern & 79.3 & {$[76.2-82.0]$} & 20.7 & [18.0-23.8] & \\
\hline Western & 83.5 & {$[80.5-86.1]$} & 16.5 & [13.9-19.5] & \\
\hline Total & 82.6 & {$[81.2-83.9]$} & 17.4 & [16.1-18.8] & \\
\hline \multicolumn{6}{|l|}{ Urban or Rural residence } \\
\hline Urban & 78.6 & {$[75.0-81.8]$} & 21.4 & {$[18.2-25.0]$} & \multirow{3}{*}{$\begin{array}{l}X^{2}(1)=14.7354 ; \text { Design-based } F(1.00 \\
4770.00)=8.3113 \mathbf{P}=\mathbf{0 . 0 0 4}\end{array}$} \\
\hline Rural & 83.7 & {$[82.2-85.1]$} & 16.3 & {$[14.9-17.8]$} & \\
\hline Total & 82.6 & {$[81.2-83.9]$} & 17.4 & [16.1-18.8] & \\
\hline \multicolumn{6}{|l|}{ Sex of respondent } \\
\hline Male & 77.6 & {$[75.3-79.7]$} & 22.4 & {$[20.3-24.7]$} & \multirow{3}{*}{$\begin{array}{l}X^{2}(1)=67.4419 ; \text { Design-based } F(1.00 \\
4770.00)=41.6579 P=\mathbf{P} .000\end{array}$} \\
\hline Female & 86.7 & [84.9-88.3] & 13.3 & [11.7-15.1] & \\
\hline Total & 82.6 & {$[81.2-83.9]$} & 17.4 & [16.1-18.8] & \\
\hline \multicolumn{6}{|l|}{ Head of household } \\
\hline not head & 85.4 & {$[83.4-87.3]$} & 14.6 & [12.7-16.6] & \multirow{3}{*}{$\begin{array}{l}X^{2}(1)=19.3278 ; \text { Design-based } F(1.00 \\
4770.00)=12.0582 \mathbf{P}=\mathbf{0 . 0 0 1}\end{array}$} \\
\hline Head & 80.5 & {$[78.6-82.3]$} & 19.5 & {$[17.7-21.4]$} & \\
\hline Total & 82.6 & {$[81.2-83.9]$} & 17.4 & [16.1-18.8] & \\
\hline \multicolumn{6}{|l|}{ Marital status } \\
\hline Other & 84.9 & {$[81.3-87.9]$} & 15.1 & {$[12.1-18.7]$} & \multirow{4}{*}{$\begin{array}{l}X^{2}(2)=8.1345 ; \text { Design-based } F(1.98 \\
9446.38)=2.7399 \mathbf{P}=\mathbf{0 . 0 6 5}\end{array}$} \\
\hline Single & 85.8 & [81.8-89.0] & 14.2 & [11.0-18.2] & \\
\hline Married & 81.7 & {$[80.0-83.3]$} & 18.3 & {$[16.7-20.0]$} & \\
\hline Total & 82.6 & {$[81.2-83.9]$} & 17.4 & [16.1-18.8] & \\
\hline \multicolumn{6}{|l|}{ Ever attended school } \\
\hline Never attended school & 89.6 & {$[87.1-91.7]$} & 10.4 & [8.3-12.9] & \multirow{3}{*}{$\begin{array}{l}X^{2}(1)=41.4547 ; \text { Design-based } F(1.00 \\
4770.00)=28.0364 \mathbf{P}=\mathbf{0 . 0 0 0}\end{array}$} \\
\hline Attended school & 80.8 & {$[79.2-82.4]$} & 19.2 & {$[17.6-20.8]$} & \\
\hline Total & 82.6 & {$[81.2-83.9]$} & 17.4 & [16.1-18.8] & \\
\hline \multicolumn{6}{|l|}{ Can read and write } \\
\hline Unable to read and write & 87.9 & {$[85.8-89.7]$} & 12.1 & [10.3-14.2] & \multirow{3}{*}{$\begin{array}{l}X^{2}(1)=52.2933 ; \text { Design-based } F(1.00 \\
4770.00)=32.8182 \quad P=0.000\end{array}$} \\
\hline Able to read at least & 79.6 & {$[77.8-81.4]$} & 20.4 & [18.6-22.2] & \\
\hline Total & 82.6 & {$[81.2-83.9]$} & 17.4 & [16.1-18.8] & \\
\hline \multicolumn{6}{|l|}{ Employment status } \\
\hline Not employed & 84.6 & {$[82.0-87.0]$} & 15.4 & [13.0-18.0] & \multirow{3}{*}{$\begin{array}{l}X^{2}(1)=5.3350 ; \text { Design-based } F(1.00 \\
4770.00)=3.2375 \mathbf{P}=\mathbf{0 . 0 7 2}\end{array}$} \\
\hline Employed & 81.8 & {$[80.1-83.4]$} & 18.2 & [16.6-19.9] & \\
\hline Total & 82.6 & {$[81.2-83.9]$} & 17.4 & [16.1-18.8] & \\
\hline \multicolumn{6}{|l|}{ Disability status } \\
\hline Disabled & 83.6 & {$[81.5-85.4]$} & 16.4 & {$[14.6-18.5]$} & \multirow{3}{*}{$\begin{array}{l}X^{2}(1)=2.9718 ; \text { Design-based } F(1.00 \\
4770.00)=1.8346 P=0.176\end{array}$} \\
\hline Not disabled & 81.7 & {$[79.7-83.5]$} & 18.3 & {$[16.5-20.3]$} & \\
\hline Total & 82.6 & {$[81.2-83.9]$} & 17.4 & [16.1-18.8] & \\
\hline \multicolumn{6}{|c|}{ Dwelling unit decency status } \\
\hline Not decent & 84.0 & {$[82.0-85.9]$} & 16 & {$[14.1-18.0]$} & \\
\hline
\end{tabular}


Table 2 Factors associated with health and human rights (knowledge and assessment) (Continued)

\begin{tabular}{|c|c|c|c|c|c|}
\hline Decent dwelling & 81.4 & {$[79.4-83.2]$} & 18.6 & [16.8-20.6] & \multirow{2}{*}{$\begin{array}{l}\text { chi2 }(1)=5.7662 ; \text { Design-based } F(1.00 \\
4770.00)=3.6264 \boldsymbol{P}=\mathbf{0 . 0 5 7}\end{array}$} \\
\hline Total & 82.6 & {$[81.2-83.9]$} & 17.4 & {$[16.1-18.8]$} & \\
\hline \multicolumn{6}{|c|}{ House ownership status } \\
\hline Not own/free & 81.1 & {$[77.5-84.3]$} & 18.9 & {$[15.7-22.5]$} & \\
\hline Own/free & 82.9 & [81.4-84.4] & 17.1 & [15.6-18.6] & \multirow{2}{*}{$\begin{array}{l}X^{2}(1)=1.6285 ; \text { Design-based } F(1.00 \\
4770.00)=0.9812 \boldsymbol{P}=\mathbf{0 . 3 2 2}\end{array}$} \\
\hline Total & 82.6 & [81.2-83.9] & 17.4 & {$[16.1-18.8]$} & \\
\hline \multicolumn{6}{|l|}{ Source of water } \\
\hline Public & 82.7 & {$[81.1-84.2]$} & 17.3 & [15.8-18.9] & \\
\hline Private & 77.4 & {$[70.4-83.2]$} & 22.6 & [16.8-29.6] & \multirow{3}{*}{$\begin{array}{l}X^{2}(2)=7.6536 ; \text { Design-based F(1.96, } \\
9343.03)=2.1905 \boldsymbol{P}=\mathbf{0 . 1 1 3}\end{array}$} \\
\hline Protected & 84.3 & [80.8-87.2] & 15.7 & [12.8-19.2] & \\
\hline Total & 82.6 & {$[81.2-83.9]$} & 17.4 & {$[16.1-18.8]$} & \\
\hline \multicolumn{6}{|l|}{ Source of lighting } \\
\hline Paraffin & 83.1 & {$[81.4-84.7]$} & 16.9 & [15.3-18.6] & \\
\hline Public & 78.3 & {$[74.2-81.9]$} & 21.7 & {$[18.1-25.8]$} & \multirow{3}{*}{$\begin{array}{l}X^{2}(2)=9.2866 ; \text { Design-based F(1.98, } \\
9460.88)=2.9893 \boldsymbol{P}=\mathbf{0 . 0 5 1}\end{array}$} \\
\hline Private & 83.6 & {$[80.4-86.5]$} & 16.4 & {$[13.5-19.6]$} & \\
\hline Total & 82.6 & [81.2-83.9] & 17.4 & [16.1-18.8] & \\
\hline \multicolumn{6}{|l|}{ Land ownership status } \\
\hline Do not own land & 82.7 & {$[79.7-85.4]$} & 17.3 & {$[14.6-20.3]$} & \\
\hline Own land & 82.6 & [81.0-84.1] & 17.4 & [15.9-19.0] & \multirow{2}{*}{$\begin{array}{l}X^{2}(1)=0.0129 ; \text { Design-based } F(1.00 \\
4770.00)=0.0083 \boldsymbol{P}=\mathbf{0 . 9 2 8}\end{array}$} \\
\hline Total & 82.6 & {$[81.2-83.9]$} & 17.4 & {$[16.1-18.8]$} & \\
\hline \multicolumn{6}{|l|}{ Meals per day } \\
\hline Less than three meals & 83.9 & {$[82.2-85.4]$} & 16.1 & {$[14.6-17.8]$} & \\
\hline Three or more meals & 79.4 & [76.7-81.9] & 20.6 & {$[18.1-23.3]$} & \multirow{2}{*}{$\begin{array}{l}X^{2}(1)=13.6498 ; \text { Design-based F(1.00, } \\
4770.00)=8.7547 \boldsymbol{P}=\mathbf{0 . 0 0 3}\end{array}$} \\
\hline Total & 82.6 & [81.2-83.9] & 17.4 & {$[16.1-18.8]$} & \\
\hline \multicolumn{6}{|l|}{ Granary availability } \\
\hline No granary & 83.2 & {$[81.6-84.8]$} & 16.8 & [15.2-18.4] & \multirow{3}{*}{$\begin{array}{l}X^{2}(1)=3.1387 ; \text { Design-based } F(1.00 \\
4770.00)=1.9306 \boldsymbol{P}=\mathbf{0 . 1 6 5}\end{array}$} \\
\hline Has granary & 81.1 & [78.4-83.6] & 18.9 & {$[16.4-21.6]$} & \\
\hline Total & 82.6 & {$[81.2-83.9]$} & 17.4 & {$[16.1-18.8]$} & \\
\hline
\end{tabular}

number of predictors for the hybrid human rights observance as provided in the conceptual framework in Figure 1. The models were developed such that model one contained all the preconceived variables necessary for assessing level of observance of human rights. Model two was constructed such that it excludes the four location variables (urbanrural, dwelling, ownhouse and ownland) whereas model three excluded the four services-based variables (watersource, lighting, granary and meals) besides the location variables. This was designed so as to study the model dynamics for changes in assessment of human rights observance when influential characteristics of location and service provision are controlled.

It was observed that for all variables that significantly predicated level of observance of human rights in the three models bore a consistent behaviour throughout the modelling cycle. The odds for reporting that human rights are respected were greater for the respondents who were heads of households, married, ever attended school, could read and write, employed, had three or more meals per day, had a granary, owned land and dwelled in a decent unit. Notably, the odds for reporting that human rights are respected were less for respondents; who were female, had no disability, had private sources of water and lighting, owned a house and resided in a rural area. Accordingly, the entire model diagnostic tests (Log-likelihood ratio test, Akaike information criterion and Bayesian information criterion) shown recommend model one as the most reliable and coherent human rights observance predictor model.

Figure 2 shows the probabilities for the levels of prediction of human rights by the different covariates based on estimates from models one, two and three presented in Table 2. Furthermore, using the graphical evidence, it is confirmed that model one portrayed the best estimate of human rights observance followed by model two and model three respectively. Model one is one which utilised all variables in its estimation of human rights 
Table 3 Determinants of health and human rights (knowledge and assessment) at national level

\begin{tabular}{|c|c|c|c|}
\hline Dependent: Human rights status & HR Model one OR (S.E) & HR Model two OR (S.E) & HR Model three OR (S.E) \\
\hline \multicolumn{4}{|l|}{ Sex of respondent } \\
\hline Male & 1.000 & 1.000 & 1.000 \\
\hline Female & $0.610^{* *}(0.001)$ & $0.621^{* *}(0.001)$ & $0.617^{* *}(0.001)$ \\
\hline \multicolumn{4}{|l|}{ Head of household } \\
\hline Not head & 1.000 & 1.000 & 1.000 \\
\hline Head & $1.077^{* *}(0.003)$ & $1.081^{* *}(0.003)$ & $1.066^{* *}(0.002)$ \\
\hline \multicolumn{4}{|l|}{ Marital status } \\
\hline Single & 1.000 & 1.000 & 1.000 \\
\hline Married & $1.075^{* *}(0.001)$ & $1.076^{* *}(0.001)$ & $1.076^{* *}(0.001)$ \\
\hline \multicolumn{4}{|l|}{ Ever attended school } \\
\hline Never attended school & 1.000 & 1.000 & 1.000 \\
\hline Attended school & $1.343^{* *}(0.004)$ & $1.342^{* *}(0.004)$ & $1.356^{* *}(0.004)$ \\
\hline \multicolumn{4}{|l|}{ Can read and write } \\
\hline Unable to read and write & 1.000 & 1.000 & 1.000 \\
\hline Able to read at least & $1.362^{* *}(0.003)$ & $1.435^{* *}(0.004)$ & $1.456^{* *}(0.004)$ \\
\hline \multicolumn{4}{|l|}{ Employment status } \\
\hline Not employed & 1.000 & 1.000 & 1.000 \\
\hline Employed & $1.078^{* *}(0.002)$ & $1.087^{* *}(0.002)$ & $1.074^{* *}(0.002)$ \\
\hline \multicolumn{4}{|l|}{ Disability status } \\
\hline Disabled & 1.000 & 1.000 & 1.000 \\
\hline Not disabled & $0.952^{* *}(0.002)$ & $0.973^{* *}(0.002)$ & $0.982^{* *}(0.002)$ \\
\hline Age & $1.000^{* *}(0.000)$ & $1.001^{* *}(0.000)$ & $1.001^{* *}(0.000)$ \\
\hline \multicolumn{4}{|l|}{ Meals per day } \\
\hline less than three meals & 1.000 & 1.000 & \\
\hline three or more meals & $1.217^{* *}(0.002)$ & $1.268^{* *}(0.002)$ & \\
\hline \multicolumn{4}{|l|}{ Granary availability } \\
\hline No granary & 1.000 & 1.000 & \\
\hline Nas granary & $1.143^{* *}(0.002)$ & $1.151^{* *}(0.002)$ & \\
\hline \multicolumn{4}{|l|}{ Source of water } \\
\hline Public & 1.000 & 1.000 & \\
\hline Private & $0.925^{* *}(0.001)$ & $0.946^{* *}(0.001)$ & \\
\hline \multicolumn{4}{|l|}{ Source of lighting } \\
\hline Public & 1.000 & 1.000 & \\
\hline Private & $0.995^{* *}(0.001)$ & $0.997^{* *}(0.001)$ & \\
\hline \multicolumn{4}{|l|}{ Land ownership status } \\
\hline Do not own land & 1.000 & & \\
\hline Own land & $1.021^{* *}(0.003)$ & & \\
\hline \multicolumn{4}{|l|}{ House ownership status } \\
\hline Not own/free & 1.000 & & \\
\hline Own/free & $0.951^{* *}(0.003)$ & & \\
\hline \multicolumn{4}{|l|}{ Dwelling unit decency status } \\
\hline Not decent & 1.000 & & \\
\hline Decent dwelling & $1.199 * *(0.002)$ & & \\
\hline
\end{tabular}

Urban or Rural residence 
Table 3 Determinants of health and human rights (knowledge and assessment) at national level (Continued)

\begin{tabular}{lll}
\hline Urban & 1.000 & \\
Rural & $0.874^{* *}(0.001)$ & \\
Model diagnostic checks & & 4771 \\
Number of households & 4771 & $-4.20 \mathrm{E}+06$ \\
Log-likelihood & $-4.19 \mathrm{E}+06$ & 12 \\
Degrees of freedom & 16 & $8.41 \mathrm{E}+06$ \\
Akaike information criterion & $8.39 \mathrm{E}+06$ & $8.22 \mathrm{E}+06$ \\
Bayesian information criterion & $8.39 \mathrm{E}+06$ & $8.41 \mathrm{E}+06$ \\
\hline
\end{tabular}

Note: Odds Ratio (OR); standard error (S.E) in parentheses; $\left(+=p<0.10,{ }^{*}=p<0.05,{ }^{* *}=p<0.01\right)$; for completeness, the 1.000 represent base categories.

observance. The level of reliability of estimates for human rights observance could also be determined from the plot's proximity to the normal distribution. Overall, the proportion of the human rights observance that was estimated using any of the three models is about 20 percent that may stretch up to a maximum of 40 percent for model one.

\section{Discussions}

The two strands derived from the findings support the conceptual framework presented in this study. Firstly, the multivariate statistical model analyses show that the model with a complete set of covariates as suggested provides the best fit to the baseline survey according to the diagnostic tests (Log-likelihood ratio test, Akaike information criterion and Bayesian information criterion) presented in Table 2. Having passed the goodness of fit test using Hosmer-Lemeshow test, further tests were performed to establish the best model among the three proposed. The model with the best fit was identified as one with the smallest value for anyone of the three diagnostic tests applied. All the three model candidates show the exponentiated coefficients, commonly referred to as the odds ratios. These odds ratios, though, do not contradict for any one model, they present intrinsic differences. For example, female household respondents are less likely to report that human rights are observed than the male counterparts by about 39 percent. The other determinants with negative odds include; female respondents, households with private water source,

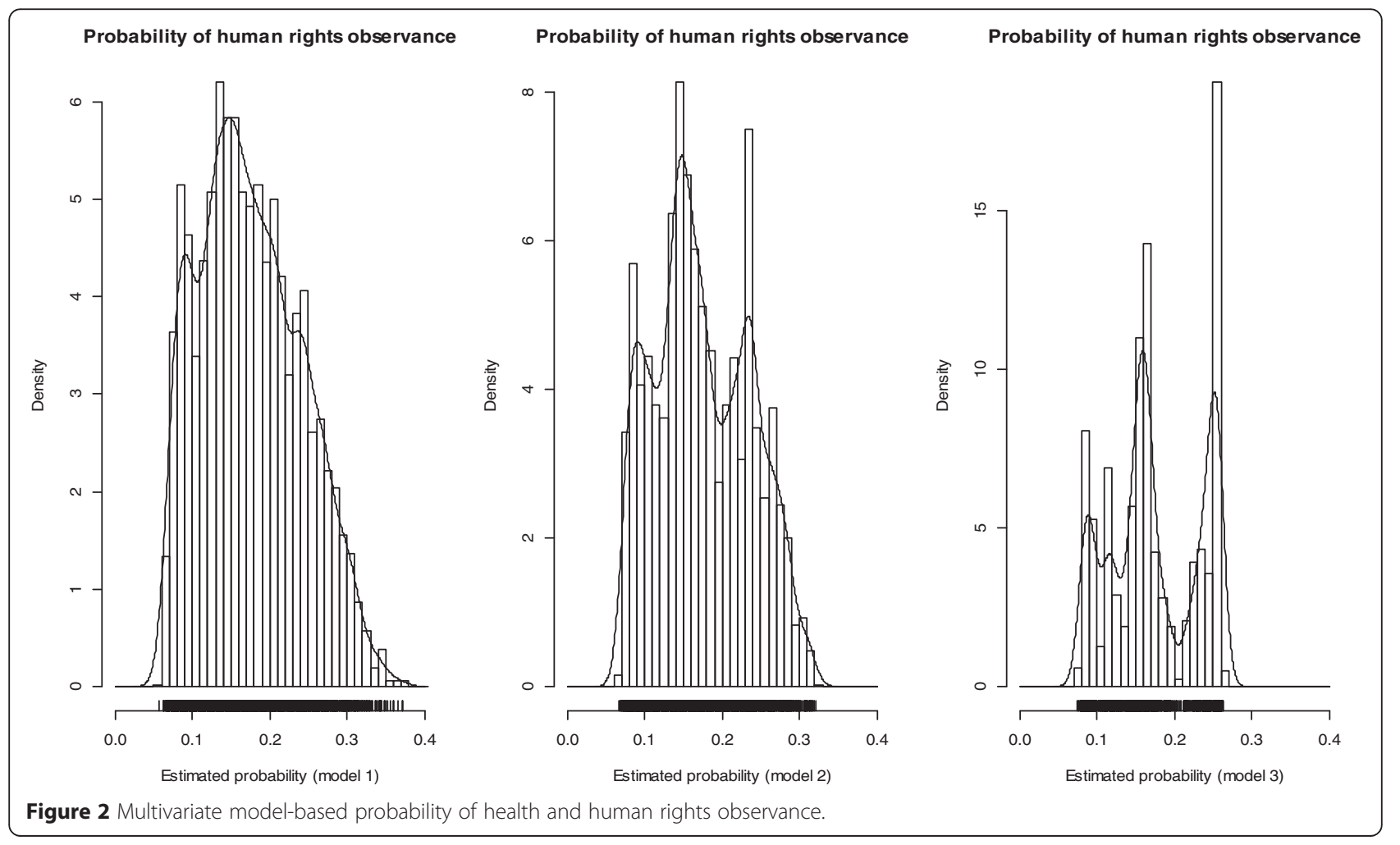


households with private lighting source, respondents who own land and those who stay in rural areas. Respondents who are heads of households are more likely to report that human rights are observed than those respondents who are not heads of households by about 8 percent. The other determinants with positive odds include; head of household, those who attended school, those who can read and write, those who are employed, those who can afford three or meals per day, those with a granary, those who own land and those with decent dwelling. The best model fit tends to present a more optimal position for evaluating the level of human rights observance, hence the health status of households and the communities as a whole. Secondly, the bivariate plot, Figure 2 shows that models 2 and 3 greatly distort the known normal distribution curve $N(\mu=0 ; \sigma=1)$ that leaves model 1 as the best fit, thus may not adequately be used to determine the level of health and human rights adherence [17].

From the theoretical perspective, health and human rights present to the development and health planners a very intricate scenario that is sometimes difficult to quantify $[11,45,46]$. However, principally, human rights observance presents two components; the indelible rights which are more permanent and hard to continuously deny, for example the right to life and the provisional rights which are transitory or short-lived, for example the right to access electoral or public information $[47,1,48,49]$. Findings from this study (Figure 2; model one) show that the indelible human rights represent at least 60 percent of the overall human rights; these rights were not measured, but were implied from the best human rights observance model one that estimated the provisional human rights to be about 40 percent. This is a very significant contribution not only to the literature of human rights, but also to the wealth of knowledge of statistical, health and development studies involving human rights observance levels.

Furthermore, it can still be shown that judgement or assessment of health and human rights, where only respondents are involved, will on average be 20 percent of the entire human rights observance assessment. The argument for this conclusion is that while assessing human rights, there are two sides; the demand side and the supply side. Therefore, interaction with a typical citizen as an assessor will lead to an average estimate of 20 percent as shown in Figure 1 of this study. This is one of the main limitations of assessing human rights using household survey data whose acknowledgement could improve reliability of human rights assessments.

\section{Conclusions}

In summary, the study explored the possibility of developing a system of assessing levels of human rights in the context of health based using household survey methodology. The key determinants of health and human rights were established using survey data. Accordingly all variables proposed in the study were significant $(p<0.01)$, as they generated the best model (model 1) to estimate national-level human rights observance. Seemingly, at bivariate level, using the $\chi^{2}$ - test and design-based F-test statistics, there were slight variations in the associations of the hybrid variable and parameters that explained it. Findings show that to assess health and human rights observance, the household survey methodology approach yields an average of 20 percent of the entire human rights continuum as revealed by the three different human rights observance models presented in this study. Ironically, suggesting that 20 percent is demanded from governments, the other 20 percent are on the supply side as protected through constitutions and the biggest percentage $(60 \%)$ are the indelible human rights, God-given and protected. Higher probabilities of observance imply better levels of health and livelihoods experienced. Lastly, findings of this study are instrumental in developing and harmonising health, human rights and national development.

\section{Competing interests}

The authors declare that they have no competing interests.

\section{Authors' contributions}

RW conceived of the study and participated in its design, data collection, performed the statistical analysis, modelling and write up of the manuscript. AO participated in the design, carried out data collection, analysis and proofread the manuscript. LA participated in data collection, analysis and proofread the manuscript. AS participated in the design of the study, performed the statistical analysis and proofread the manuscript. PJ participated in the data collection and coordination and proofread the manuscript. All authors read and approved the final manuscript.

\section{Acknowledgements}

First, we acknowledge the three anonymous reviewers for their constructive comments that shaped this paper in its current improved form. We also recognise the contribution by the School of Statistics and Planning and the Uganda Bureau of Statistics for successfully conducting the first-ever National Governance Baseline Survey whose data were used in this study.

Received: 7 November 2014 Accepted: 24 April 2015 Published online: 03 May 2015

\section{References}

1. Donnelly J. Universal human rights in theory and practice. Cornell University Press; 2013.

2. Skogly S. Human Rights Obligations of the World Bank and the IMF, Routledge. 2012.

3. Vizard P, Fukuda-Parr S, Elson D. Introduction: the capability approach and human rights. J Human Dev Cap. 2011;12(1):1-22.

4. Turner BS. Vulnerability and human rights. Penn State Press; 2010

5. Darch C. Statistics, indicators and access to information in African countries. Access Info Africa: Law, Cult Pract. 2013;1:109.

6. Hamer D. Probability, anti-resilience, and the weight of expectation. Law Prob Risk. 2012;11(2-3):135-58. doi: 10.1093/lpr/mgs004.

7. Merry SE. Measuring the World: Indicators, Human Rights and Global Governance. Curr Anthropol. 2011;52(S3):S83-95. doi:10.1086/657241.

8. Shelton D, Carozza PG. Regional protection of human rights. Oxford University Press; 2013.

9. Hill DW. Estimating the effects of human rights treaties on state behavior. J Pol. 2010;72(04):1161-74. 
10. Goodhart M. Democracy as human rights: freedom and equality in the age of globalization. Routledge. 2013.

11. de Beco G. Human rights indicators: from theoretical debate to practical application. J Human Rights Prac. 2013;5(2):380-97.

12. World Bank G. World Development Indicators 2012. World Bank: Publications; 2012.

13. NPA. Uganda Vision 2040. 2013

14. UBOS. SSP-MAK. Kampala: Uganda National Governance Baseline Survey; 2014.

15. NPA. Uganda National Planning Programme 2010/11 - 2014/15. vol 2010. 2010.

16. Agbakwa SC. Reclaiming humanity: economic, social, and cultural rights as the cornerstone of African human rights. Yale Human Rights Dev J. 2014;5(1):5.

17. Wesonga R, Nabugoomu F, Owino A, Atuhaire L, Ssekiboobo A, Mugisha X, et al. On statistical definition of free and fair election: bivariate normal distribution model. Intl J Mathematical Res. 2014;3(5):49-62.

18. Steiner HJ, Alston P, Goodman R. International human rights in context. Oxford: Clarendon; 1996

19. Odoki BJ. The search for a national consensus: the making of the 1995 Uganda Constitution. Uganda: Fountain Pub Ltd; 2005.

20. Johnson K, Scott J, Rughita B, Kisielewski M, Asher J, Ong R, et al. Association of sexual violence and human rights violations with physical and mental health in territories of the Eastern Democratic Republic of the Congo. JAMA. 2010;304(5):553-62

21. Assembly UNG. Universal Declaration of Human Rights, 10 December 1948, 217 A (III). 2011.

22. Renteln AD. International human rights: universalism versus relativism. Quid Pro Books; 2013.

23. Cook RJ. Human rights of women: National and international perspectives. University of Pennsylvania Press; 2013.

24. Ife J. Human rights and social work: Towards rights-based practice. Cambridge University Press; 2012

25. Clark AM, Sikkink K. Information effects and human rights data: is the good news about increased human rights information bad news for human rights measures? Human Rights Q. 2013;35(3):539-68.

26. Governance C Team. Uganda National Governance Baseline Survey, Uganda Bureau of Statistics and School of Statistics and Planning. Kampala: Makerere University; 2014.

27. Bertrand JT, Escudero G, Soukaloun D, Kounnavong S, Pengdy B, Boupha B, et al. Compendium of indicators for evaluating reproductive health programs. Volume 2. Ann Trop Paediatr. 2013;23(2):181-6.

28. Dowler EA, O'Connor D. Rights-based approaches to addressing food poverty and food insecurity in Ireland and UK. Soc Sci Med. 2012;74(1):44-51.

29. Tomuschat C. Human rights: between idealism and realism. Oxford University Press; 2014.

30. Hall RP, Van Koppen B, Van Houweling E. The human right to water: the importance of domestic and productive water rights. Sci Eng Ethics. 2014;20(4):849-68.

31. United Nations High Commissioner for Human Rights. The Right to Adequate Housing. Factsheet No. 21. Rev. 1. Palais des Nations, 8-14 avenue de la Paix, CH-1211. Switzerland: Geneva 10; 2014.

32. Owino AY, Atuhaire LK, Wesonga R, Nabugoomu F, Muwanga-Zaake ESK. Determining Factors that Influence Household Food Insecurity in Uganda: a case study of Tororo and Busia districts. Intl J Sci: Basic App Res (IJSBAR). 2014;14(1):394-404.

33. Harris D, O'Boyle M, Bates E, Buckley C. Harris, O'Boyle, and Warbrick Law of the European Convention on Human Rights. Oxford: Oxford University Press; 2014.

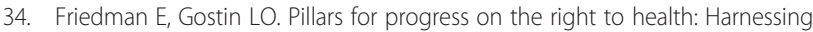
the potential of human rights through a Framework Convention on Global Health. Health Human Rights J. 2012;14(1):1-16.

35. London L, Schneider H. Globalisation and health inequalities: Can a human rights paradigm create space for civil society action? Soc Sci Med. 2012;74(1):6-13.

36. Meier BM, Brodish PH, Koivusalo M. Human rights provide justification for the Health in All Policies approach. Health and Human Rights: Int J; 2013.

37. Mpinga EK, Chastonay P. Satisfaction of patients: a right to health indicator? Health Pol. 2011;100(2):144-50.

38. Cingranelli DL, Richards DL. The Cingranelli and Richards (CIRI) human rights data project. Human Rights Q. 2010;32(2):401-24.
39. Burchardt T, Vizard P. 'Operationalizing' the capability approach as a basis for equality and human rights monitoring in twenty-first-century Britain. J Human Dev Cap. 2011;12(1):91-119.

40. Kotsoglou KN. How to become an epistemic engineer: what shifts when we change the standard of proof? Law Prob Risk. 2013;12(3-4):275-98. doi: 10.1093/lpr/mgt002

41. Webb EL, Forster JJ. Bayesian model determination for multivariate ordinal and binary data. Comput Stat Data Anal. 2008;52(5):2632-49.

42. Heiberger RM, Holland B. Statistical analysis and data display : an intermediate course with examples in S-plus, R, and SAS. New York: Springer Science + Business Media; 2004.

43. Wesonga R, Nabugoomu F, Jehopio P. Parameterized framework for the analysis of probabilities of aircraft delay at an airport. J Air Trans Manag. 2012;23(0):1-4. doi:http://dx.doi.org/10.1016/j.jairtraman.2012.02.001.

44. Freund RJ, Wilson WJ, Sa P. Regression analysis : statistical modeling of a response variable. 2nd ed. Burlington, MA: Elsevier Academic Press; 2006.

45. Mascarenhas A, Coelho P, Subtil E, Ramos TB. The role of common local indicators in regional sustainability assessment. Ecol Indic. 2010;10(3):646-56.

46. Gerring J, Thacker SC, Alfaro R. Democracy and human development. J Pol. 2012;74(01):1-17.

47. Congdon P. Bayesian modelling strategies for spatially varying regression coefficients: A multivariate perspective for multiple outcomes. Comput Stat Data Anal. 2007;51(5):2586-601. doi:http://dx.doi.org/10.1016/ j.csda.2006.01.004.

48. de Beco G. Human Rights Indicators and MDG Indicators: Building a Common Language for Human Rights and Development Organisations, status: accepted. 2013.

49. Bond T, Bond M. Measure for measure: curriculum requirements and children's achievement in music education. J Appl Meas. 2010;11(4):368-83.

\section{Submit your next manuscript to BioMed Central and take full advantage of:}

- Convenient online submission

- Thorough peer review

- No space constraints or color figure charges

- Immediate publication on acceptance

- Inclusion in PubMed, CAS, Scopus and Google Scholar

- Research which is freely available for redistribution

Submit your manuscript at www.biomedcentral.com/submit
C Biomed Central 